Agro-Science Journal of Tropical Agriculture, Food, Environment and Extension Volume 20 Number 3 (July 2021) pp. 24 - 29

\title{
THE EFFECT OF MECHANIZATION ON LABOUR EMPLOYMENT AND CROPLAND EXPANSION IN NORTHERN NIGERIA
}

\author{
*Shani B.B. and Musa A. \\ Department of Crop \& Soil Sciences, Faculty of Agricultural Sciences, \\ National Open University of Nigeria, Kaduna State, Nigeria \\ Corresponding author's email: bshani@noun.ed.ng
}

\begin{abstract}
The study investigated the effects of mechanized agriculture on farm labour employment and cropland expansion due to the incursion of tractors into the country. Primary data were collected using specially design pretested schedule by interview method and using panel survey data, to analyze the effects of mechanization on labour employment and cropland expansion in northern Nigeria, respectively. A sample of 240 farmers were taken for the study. Tabular, percent and linear regression analysis were done. The study found that labour employment per cropped hectare showed a declining trend with increase in farm group size under different categories of mechanization. The inverse relationship revealed between labour employment and farm size hold true in case of operation like sowing, intercultural operation and irrigation. Hired labour and family labour both had positive and negative relationship, respectively with farm size in each category of mechanized farm. Findings also show a positive correlation between farm mechanization and cropland expansion during the survey period. Two interaction terms were introduced in the model to assess whether there are differential effects of mechanization on cropland expansion across the three districts. The results show that the effect of mechanization on farmland expansion is significantly higher among farmers in Igabi compared to Zaria. This result may be driven by the differences in access to tractors in the districts with Igabi having the highest access, then followed by Zaria.
\end{abstract}

Key Words: mechanization, labour, employment, cropland, expansion

\section{INTRODUCTION}

According to the Food and Agriculture Organization (FAO), agricultural mechanization generally refers to the application of tools, implements, and powered machinery as inputs to achieve agricultural production. It encompasses various technologies across the production-processing chain from basic tools such as hoes and cutlasses to motorized equipment such as tractors and grain milling machines. The importance of mechanization in Nigeria stems from its recognition as the pivot to agricultural revolution in many parts of the world, contributing greatly to the increased output. In this vein, Nigeria needs to enhance the number of farmers who utilize mechanical power-based mechanization in order to (i) increase the food production capacity of farmers leading to reduced poverty and improved livelihoods, (ii) reduce the drudgery associated with agricultural production, (iii) reduce the level of post-harvest losses that occur across different agricultural value chains, and (iv) increase the prospects of the local agro-allied industry and the conversion of crops and tubers to value added products (VAPs). While Looking Beyond Tractors revealed that Crop production involves labour-intensive activities such as land preparation, planting, weeding, fertilization, irrigation, crop protection and harvesting.
According to a study published by the International Conference of the West African Society of Agricultural Engineering, $90 \%$ of farmers in Nigeria conduct farm operations using hand tool technologies. This is the case because many farmers lack the resources to acquire agricultural machinery like tractors and ploughs. As a result, Nigeria's mechanization rate of 0.27 horsepower per hectare is well below the FAO's recommended rate of 1.5 horsepower per hectare. In fact, for every 10,000 hectares of arable land, farmers have access to 6 tractors. This dependency on human power has not only contributed to low agricultural productivity but also fostered the importation of food from countries like Thailand which have an average of 281 tractors per 10,000 hectares of arable land.

While Farm mechanization and land occupancy systems in Nigeria have been developing freely over the years, they are not totally separate issues. Largely saying, fear arises when the expansion of mechanized Agriculture begins to invade on the land rights of rural farmers that do not have access to mechanization. This research goes to show that, despite the fact that land is still seen as a bumper source of production in Nigeria, mechanization will start having challenges similar to a fast-developing nation, that is the quest the demand for expansion of land area will give way for marginalization of lands by farmers (Shani, 2020).

Please cite as: Shani B.B. and Musa A. (2021). The effect of mechanization on labour employment and cropland expansion in northern Nigeria. Agro-Science, 20 (3), 24-29. DOI: https://dx.doi.org/10.4314/as.v20i3.4 
Although agricultural employment share remains substantial at $48.19 \%$ (National Bureau of Statistics report for the third quarter of 2017), there is a declining trend since 2001. In the rural sector where agricultural activities predominate, there is high unemployment rate estimated at $25.6 \%$. While the evidence for Nigeria is consistent with economic theory that predicts a declining agricultural employment share as development progresses, the double challenge of high rural unemployment and manufacturing low-capacity utilization suggests a distorted structural change. The agricultural sector can best be viewed as a continuum of upstream and downstream activities whether in the sub-sector of crop, livestock, forestry or fisheries. Primary agricultural production activities whether planting/rearing, weeding/nurturing and harvesting constitute the upstream economic activities from which primary commodities emerge. Following these are postharvest or secondary activities that constitute downstream activities. The secondary activities add value to the primary product, improving its quality and rendering it less perishable. Key downstream commodity activities include: storage, processing into intermediate or final (finished) products, and marketing/distribution through domestic and/or export trade (Manyong et al., 2003) There are various approaches to forecasting employment. Ramarao et al. (2013) identified the following manpower forecasting approaches; (1) employer survey methods, (2) normbased methods (3) time-series and regression (linear/non-linear, simple/multiple) models (4) mathematical models (5) rate of returns approach, and (6) Parnes's manpower requirements approach.

Because mechanized farming reduces the drudgery of farm labor and can be instrumental in expanding cultivation into areas where there is significant amount of unutilized arable lands, such as Northern Nigeria, it is regarded as a positive development (World Bank, 2012)

Within Nigeria, the rise of mechanization has been very impressive despite introduction of policies to enhance tractor acquisition. The small but increasing presence of tractors in Nigeria has evolved as the conditions for mechanization have improved in the country. To support a farming culture based around mechanization, three conditions must be present; (1) sufficient levels of income, (2) market opportunities, and (3) a sound cash crop. The income levels in Nigeria have been improving steadily, not only in the farming sector, but also among the civil service. This allows greater numbers to set aside income for new purposes. Market opportunities have improved as banks and credit institutions have begun to make credit available to Nigerians, though still on a minor scale.

Thus, although the introduction of tractors in Nigeria has come slowly, the effects of increased Farm mechanization are no longer insignificant. Hazarika (2015) reported that labour scarcity and farm mechanization needs to be studied in detail both at macro and micro level across various farm situations to verify whether there is any linkage between micro and macro level situation. Ramya and Muruganandham (2016) reported that farm mechanization increases onfarm human labour marginally, whereas the increase in off- farm labour such as industrial production of tractors and ancillaries was much more. That farm mechanization displaced animal power to the extent of $50-100 \%$ but resulted in lesser time for farm work. Van den Berg et al. (2007) examined the effect of increasing farm size and mechanization on rural income and rice production in China. They reported that larger farm sizes labour constraints inhibit farmers from specialization in non-rice crops leads to rising per capita income. The main objective of this investigation is to determine the Farm mechanization effects on labour and employment and cropland expansion in northern Nigeria.

\section{MATERIALS AND METHODS}

\section{Study Area}

The study was conducted in the three senatorial districts of Kaduna State, Kafanchan, Igabi and Soba representing South, Central and North, respectively. From North, Soba was selected because it is ahead of other Local Government Areas in mechanization in that district; therefore, determination of mechanization effects on labour and production was conducted there. Kafanchan and Igabi represented Southern and Northern districts, respectively, and determination of effects of mechanization on cropland expansion was carried there.

Kaduna lies on $613 \mathrm{~m}$ asl and the climate is tropical. When compared with winter, the summers have much more rainfall. The average annual temperature in Kaduna is $25.2^{\circ} \mathrm{C}$. About $1211 \mathrm{~mm}$ of rainfall falls annually. Cash and food crops such as yam, cotton, groundnut, tobacco, maize, beans, guinea corn, millet, ginger, rice and cassava are cultivated in large quantities. Livestock and fisheries also have very high potentials in the State.

\section{Sampling Techniques and Sample Size}

The sampling design followed for the study was four stage random sampling design, in the determination of mechanization effects on labour. Districts from the first stage unit, blocks were the second stage unit, villages were the third and the sample farmers were the fourth ultimate stage of units of sampling. In consultation with Agricultural Development Officer (ADO) and Agricultural Engineering Department, Government of the selected states, the blocks having higher concentration of farm implements were selected. The sample household were classified into 5 sub-groups viz., tractor ownership farm (TOF), tractor hired farm (THF), power tiller ownership farm (PTOF), power tiller hired farm (PTHF), bullock operated farm (BOF). Most of the farmers in the sample were having less operational holding as most of the farmers of Nigeria is small and marginal. Only very few farmers were found to have land holding more than 3 hectares hence the stratification of groupings was made as follows: i) Group I (less than $1.00 \mathrm{ha}$ ) ii) Group II (1.00-2.00 ha) and iii) Group III (more than $2.00 \mathrm{ha}$ ). 


\section{Data Collection}

Both primary and secondary data were used for the study. Secondary data were collected from different published sources and government institutions and primary data were collected from 240 sample farms by personal interview method with the help of specially designed pretested schedule for various objectives of the study purpose. All data collected from sample pertain to the year 2018-19. Our primary data are three survey waves from the Nigeria LSMS-ISA dataset, collected jointly by the National Bureau of Statistics and the World Bank.

\section{Analysis of Data}

Tabular with averages and percentage, log linear regression analysis was carried out to find out the effect of farm mechanization on Labour employment and cropland expansion in the study. Again, for analytical tool the total utilization for each enterprise was calculated in terms of adult mandays of eight hours of work per day. For the determination of the effect of mechanization on cropland expansion, we estimated correlated random effects (CRE) models using the panel data obtained the Nigeria LSMS-ISA dataset, collected jointly by the National Bureau of Statistics and the World Bank. The sample selected is nationally representative but with narrow scope to the three Northern Regions. The panel sample was selected through stratified random sampling methods and interviewed in $2018 / 19$. Thus, a sample of 240 farmers comprising of 80 from each state of the region had been taken for entire study.

Alternative estimation methods which could be used include Pooled Ordinary Least 7 Square (POLS) with fixed or ordinary random effects. However, compared with CRE models, these methods may produce inefficient and biased results. With the fixed effect approach, the model can be specified as follows:

$$
y_{i}=\alpha_{i}+X_{i i} \boldsymbol{\beta}+\mu_{i i}
$$

where $\alpha$ i captures all the household unobserved, timeconstant factors that affect cropland expansion(ity). The underlying assumption of the fixed effects specification is that the explanatory variables $\left(\mathrm{X}_{\mathrm{it}}\right)$ and unobserved heterogeneity $\left(\alpha_{i}\right)$ are correlated.

However, if the unobserved heterogeneity is uncorrelated with any of the explanatory variables in all time periods, then estimating equation 1 using fixed effect is inefficient. An alternative is to estimate a random effect model which allows the inclusion of time-constant variables as follows:

$$
y_{i j}=\boldsymbol{\beta}_{o}+\boldsymbol{X}_{i i} \boldsymbol{\beta}+\mathcal{E}_{i i},
$$

where $\mathcal{E}_{i i}=\alpha_{i}+\mu_{i t}$

However, this specification still assumes that the fixed effect factor is uncorrelated with the explanatory variables, which may not be the case. To overcome the shortcomings of both fixed and random effects estimators, we used the correlated random effects (CRE) or the Mundlak Chamberlain device proposed by Mundlak (1978) and Chamberlain (1984), where we included time average variables for all time variant explanatory variables in our estimation. With a CRE model, the household unobserved time constant factors, $\alpha$ i are modelled as follows:

$$
\alpha_{i}=\delta+\varphi \overline{X_{i}}+\varsigma_{i}, \varsigma_{i} \mid X_{i} \sim N\left(O, \sigma_{c}^{2}\right) .
$$

where $X_{i}$ represents the time-averaged $X_{i t}$ over the various panel periods. This model allows controlling for unobserved time-constant heterogeneity as with fixed effects as well as measuring the effects of timeinvariant independent variables as with random effects models specified in equations 1 and 2, respectively. In general, the CRE model unifies both the fixed and random effects estimation approaches. The drawbacks of the CRE estimator are that we have to impose somewhat 8 strong assumptions, such as a strict exogeneity conditional on $\alpha \mathrm{i}$ and a standard normal distribution on the estimated model.

\section{RESULTS AND DISCUSSIONS}

Mechanization Effects on Labour and Employment Labour Employment per cropped hectare effect of farm mechanization on hired and family labour is presented in Table 1, which showed the distribution of family and hired (both permanent and casual) labour for different categories of mechanized and bullock operated farm.

Table 1 shows that out of total labour employment family labour employment was found to be 3.70, 58.91, 20.30, 63.02 and $91.22 \%$ in case of TOF, THF, PTOF, PTHF and BOF, respectively, while hired labour employment was 96.30, 41.09, 79.70, 36.98 and 8.78\%, respectively. Family labour employment was higher in case of PTOF than TOF. The lower utilization of family labour in the case of TOF might be due greater involvement. The TOF was financially sound having the capacity to pay for hired labour. Further, in the case of TOF and PTOF, the households utilized permanent hired labour; however, permanent labour involvement was nil in the case of THF, PTHF and BOF. This might be due to the reason of seasonal nature of agricultural crops along with farmers in these categories were relatively poor and not capable to invest wage by engaging labour permanently. Again, in the case of $\mathrm{BOF}$, involvement of family labour was found to be highest, i.e., $91.22 \%$ indicated that BOF had primary occupation in agriculture followed by wage earning.

Table 2 shows labour utilization of different size group under various categories of mechanized and bullock operated farm and revealed that family labour decreased with the increase in the farm size. Thus, hired labour had positive relationship with farm size in the categories of mechanized and bullock operated farm, while family labour had negative relationship with farm size within each of these categories of mechanized and bullock operated farm.

Evidently, with mechanization, there is the need for land expansion; farmers can and must cultivate larger areas to ensure sufficient incentive for their investment in mechanization. The fears generated by this expansion may be mitigated, of course, if the change leads to less 
Table 1: Distribution of labour per cropped hectare under various categories of mechanization

\begin{tabular}{|c|c|c|c|c|c|c|}
\hline \multirow{2}{*}{$\mathrm{S} / \mathrm{N}$} & \multirow{2}{*}{ Categories of farms } & \multirow{2}{*}{ Family labour } & \multicolumn{3}{|c|}{ Hired labour } & \multirow{2}{*}{ Total human labour } \\
\hline & & & Permanent & Casual & Total & \\
\hline 1 & TOF & $1.98(3.70)$ & $13.39(25.00)$ & $38.19(71.30)$ & $51.58(96.30)$ & $53.56(100.00)$ \\
\hline 2 & THF & $41.26(58.91)$ & - & 28.78 (41.09) & 28.78 (41.09) & $70.04(100.00)$ \\
\hline 3 & PTOF & $13.98(20.30)$ & $7.45(10.82)$ & $47.44(68.88)$ & $54.89(79.70)$ & $68.76(100.00)$ \\
\hline 4 & PTHF & $55.11(63.02)$ & - & $32.34(36.98)$ & $32.34(36.98)$ & $87.45(100.00)$ \\
\hline 5 & BOF & $134.91(91.22)$ & - & $12.99(8.78)$ & $12.99(8.78)$ & $147.90(100.00)$ \\
\hline
\end{tabular}

Table 2: Distribution of family and hired labour per cropped hectare under various categories of mechanization

\begin{tabular}{|c|c|c|c|c|c|c|c|}
\hline \multirow{2}{*}{$\mathrm{S} / \mathrm{N}$} & \multirow{2}{*}{$\begin{array}{l}\text { Categories } \\
\text { of farms }\end{array}$} & \multirow{2}{*}{ Farm size } & \multirow{2}{*}{ Family labour } & \multicolumn{3}{|c|}{ Hired labour } & \multirow{2}{*}{ Total human labour } \\
\hline & & & & Permanent & Casual & Total & \\
\hline 1 & TOF & Group III & $1.98(3.70)$ & $13.39(25.00)$ & $38.19(71.30)$ & $51.58(96.30)$ & $53.56(100.00)$ \\
\hline \multirow[t]{3}{*}{2} & THF & Group I & $43.56(60.55)$ & - & $28.38(39.45)$ & $28.38(39.45)$ & $71.94(100.00)$ \\
\hline & & Group II & $38.95(57.70)$ & - & $28.56(42.30)$ & $28.56(42.30)$ & $67.51(100.00)$ \\
\hline & & Group III & $27.55(43.88)$ & $8.88(14.14)$ & $26.36(41.98)$ & $35.24(56.12)$ & $62.79(100.00)$ \\
\hline \multirow[t]{2}{*}{3} & PTOF & Group II & $14.67(21.34)$ & $6.75(9.82)$ & $47.34(68.85)$ & $54.09(78.56)$ & $68.76(100.00)$ \\
\hline & & Group III & $13.45(21.34)$ & 7.98 (11.57) & $47.5(68.93)$ & $55.52(80.30)$ & $68.79(100.00)$ \\
\hline \multirow[t]{2}{*}{4} & PTHF & Group I & $57.9(64.91)$ & - & $31.3(35.09)$ & $31.30(35.09)$ & $89.20(100.00)$ \\
\hline & & Group II & $51.03(60.11)$ & - & $33.89(39.89)$ & 33.89 (39.89) & $84.89(100.00)$ \\
\hline \multirow[t]{2}{*}{5} & BOF & Group I & $135.8(92.32)$ & - & $11.29(7.68)$ & $11.29(7.68)$ & $147.09(100.00)$ \\
\hline & & Group II & $132.53(88.34)$ & - & $17.50(11.66)$ & $17.50(11.66)$ & $150.03(100.00)$ \\
\hline
\end{tabular}

Figures within parentheses indicate percentage of the total

labour exploitation and improved food production. Unfortunately, this has not been the case. An increase in intensity of mechanization is associated with increase in labour expenditure due to larger areas cultivated and employment of skilled labour to operate the machinery. Intensification of mechanization increases hired labour expenditure but decreases amount of family labour used (Verma, 2006)

In almost all parts of Nigeria, men till the fields and while women mostly do the weeding and harvesting. With mechanization, tractors till greater expanses of land with less labour, thereby, rendering the male labourers displaced and their short-term tilling employment is eliminated. Perhaps more significant, however, is the exploitation of women that tractors provoke (Tersiguel, 1995), Because harvesting equipment are not affordable to the farmers in Nigeria, women are forced to keep up with the tractors by hand. Thus, just as work is taken away from men, more is demanded of women. They are typically not paid for their work in the fields, as men may be during the intense tilling period. Rather, women in the extended family of a tractor farmer are pressured to "do their part" when harvesting time arrives. The strict separation of tasks between men and women precludes the possibility of reallocating to men the extra harvesting labour that tractor-tilled fields create, so that tractors actually have a harmful, exploitative effect on female labourers.

The end objective of farm mechanization is to enhance the overall productivity and production with the lowest cost of production. The per cent increase was comparatively low on custom hiring farms as compared to tractor-owning farms due to higher level of inputs and better control on timeliness of operations. Verma (2006) concurs that mechanization has a positive Effect on timeliness (which can result in yield increases as high as 70\%) and adds that this can also result in increased cropping intensities (of around 150\%).

\subsection{Mechanization Effect on Cropland Expansion}

Table 3 presents the net effects of the independent variables on cropland expansion. Cropland expansion is strongly correlated with both areas ploughed with a tractor and area ploughed with draft animals. A hectare increase in the area ploughed by a tractor increases cropland area by $14 \%$. Likewise, a hectare increase in the area ploughed by draft animals increases cropland area by $13 \%$ on average among draft animal users. These results suggest that farm mechanization had a positive effect on cropland expansion during the survey period. Thus, cropland expansion may have been driven partly by farm mechanization (i.e., ploughing with tractor or draft animals) in the districts during the survey period. This result is consistent with Verma (2006), Pingali (2007), and Van der Berg et al. (2007). The fact that northern Nigeria is essentially characterized by open land access (Braimoh, 2009) and pronounced farm power bottleneck during land preparation (Diao et al., 2012) may indicate that farm mechanization has had positive benefits and no adverse equity effects (e.g., little or no tenant/labour displacements) on the farming population.

Tractor ownership is weakly correlated with cropland expansion. This result may be due to the very low tractor ownership rate in the sample $(1.5 \%)$. Most tractor users rely on the tractor hiring market for ploughing their farmlands. Likewise, ownership of draft animals is not correlated with cropland expansion. With regard to the demographic variables, gender and education of the household head influenced cropland expansion, whereas the age of household head does not have any effect in the model. Compared to their male counter-parts, the area cropped by FHH declined by $24 \%$ during the survey period. However, education (formal) in terms of years of schooling of household head shows a negative relationship with cropland expansion. Higher levels of household head's education seem to have led to less cropland expansion, but this effect is very small $(-0.2 \%)$. 
Table 3: Effects of agricultural mechanization on cropland expansion

\begin{tabular}{|c|c|c|c|c|c|}
\hline \multirow[t]{2}{*}{$\mathrm{S} / \mathrm{N}$} & \multirow[t]{2}{*}{ Items Description } & \multicolumn{2}{|c|}{ Correlated Random Effects (CRE) } & \multicolumn{2}{|c|}{ Dependent variable:Log cultivated (ha) } \\
\hline & & $\begin{array}{c}\text { Coefficient } \\
\text { (A) }\end{array}$ & $\begin{array}{l}\text { Standard Error } \\
\text { (B) }\end{array}$ & $\begin{array}{l}\text { Coefficients } \\
\text { (C) }\end{array}$ & $\begin{array}{c}\text { Standard error } \\
\text { (D) }\end{array}$ \\
\hline 1 & Area ploughed by tractor & $0.150^{* * *}$ & 0.0080 & $0.150^{* * * *}$ & 0.0094 \\
\hline 2 & Area ploughed by draft power (ha) & $0.140 * * *$ & 0.0098 & $0.138 * * *$ & 0.0098 \\
\hline \multirow[t]{2}{*}{3} & Own draft animals ( $-1,0$ otherwise) & 0.041 & 0.0346 & $0.041 *$ & 0.0340 \\
\hline & Own tractor $(=1,0$ otherwise $)$ & -0.055 & 0.0996 & -0.031 & 0.2073 \\
\hline 4 & Age of household heads (years) & 0.004 & 0.0100 & 0.004 & 0.0090 \\
\hline 5 & Age of household head squared & -0.000 & 0.0002 & -0.000 & 0.0002 \\
\hline 6 & Female headed households ( $=1,0$ otherwise $)$ & -0.343 & 0.0693 & $-0.349 * * *$ & 0.0678 \\
\hline 7 & Years of education of household head & $-0.003 * *$ & 0.0022 & $-0.003 *$ & 0.0022 \\
\hline 8 & Landholding size (ha) & $0.009 * *$ & 0.0041 & $0.009^{* *}$ & 0.0030 \\
\hline 9 & Cereals reported as main crops ( $=1,0$ otherwise $)$ & $0.278 * * *$ & 0.0451 & $0.285^{* * *}$ & 0.0449 \\
\hline 10 & Legumes reported as main crops ( $=1,0$ otherwise $)$ & $0.194 * * *$ & 0.0291 & $0.193 * * *$ & 0.0284 \\
\hline 11 & Ratio of hired labour to total labour per ha (\%) & 0.075 & 0.0512 & 0.061 & 0.0499 \\
\hline 12 & Average distance from homestead to plots $(\mathrm{km})$ & $0.005^{* *}$ & 0.0029 & $0.005 * *$ & 0.0020 \\
\hline 13 & Land fragmentation (proportion of plots $<2$ acres (\%) & 0.002 & 0.0007 & 0.002 & 0.0007 \\
\hline 14 & Land fallowed (\% of total farmlands) & $-0.349 * * *$ & 0.0478 & $-0.348 * * *$ & 0.0463 \\
\hline 15 & Tenure security $(=1,0$ otherwise $)$ & -0.010 & 0.0245 & -0.008 & 0.0245 \\
\hline 16 & Credit from banks/MFI ( $1=, 0$ otherwise $)$ & 0.003 & 0.0498 & 0.020 & 0.0469 \\
\hline \multirow[t]{3}{*}{17} & District dummies & & & & \\
\hline & Kaduna (Zaria) & $-0.208^{* * *}$ & 0.0377 & $-0.380 * * *$ & 0.0592 \\
\hline & Adamawa (Song) & 0.018 & 0.0368 & $0.090 *$ & 0.0538 \\
\hline \multirow[t]{3}{*}{18} & Time $($ ref. year $=2018$ & & & & \\
\hline & Survey year $2018(=1)$ & $0.054 * * *$ & 0.0237 & $0.059 * * *$ & 0.0236 \\
\hline & Survey year 2018(=1) & 0.057 & 0.058 & $0.058 * *$ & 0.0250 \\
\hline \multirow[t]{3}{*}{19} & Interaction terms & & & & \\
\hline & Area mechanized by tractor. $*$ IGABI & & & $0.80 * * *$ & 0.0240 \\
\hline & Area mechanized by tractor*Zaria & & & $-0.030 * *$ & 0.0097 \\
\hline \multirow[t]{3}{*}{20} & Constant & -0.033 & 0.0141 & 0.006 & 0.0940 \\
\hline & Observation & 2804 & & 2804 & \\
\hline & Chi-squared & 3308.628 & & 3842.517 & \\
\hline
\end{tabular}

Sources: Author's estimation based on Field Survey, 2017-2018. Note: ref. stands for reference.

$* * *$ denotes significant at $99 \%$ level, $* *$ denotes significant at $95 \%$ level, $*$ denotes significant at $90 \%$ level

Landholding size had a positive and significant Effect on cropland expansion. Thus, one hectare increases in landholding size increased cropland by $0.8 \%$ on average during the survey period. The cultivation of grains for example cereal and legume crops had a net positive and highly significant Effect on cropland expansion. Cultivating cereals and legumes as main crops increased cropland by $18 \%$ and $9 \%$, respectively compared to other crops during the survey period. The results show that cropland expansion has been in part driven by cereal and legume production, with the Effect of cereal crops being twice that of legume crops. The average distance from homestead to farm plots shows a significant and positive relationship with cropland expansion, indicating that farmers that are farm farther from the homestead have expanded their croplands more than farmers that farm closer to the homestead. Under increasing demographic pressure, land expansion is only possible farther away from communities' homesteads where unused farmlands may be available. As expected, having more fallow lands has had a negative Effect on cropland expansion. One percent increase in the area fallowed reduces croplands by $25 \%$ on average. Allowing for fallow periods means reducing the land available for cultivation. The ratio of hired labour to total labour, farmland fragmentation, tenure security, and access to credit did not have any significant Effect on cropland expansion during the survey period. With regard to district-level effects, cropland expansion is significantly lower in Igabi as compared to Zaria. These results may be explained by district-level factors that could not be individually included in the models, such as district tractor population, proximity to Igabi (regional capital), and population density. While Igabi hosts by far the highest number of tractors, rural population density is quite high in the district, implying a higher labour to land ratio (that is, less land available for farming or expansion) compared with Zaria. Due to its proximity to Igabi, Zaria benefits greatly from tractor owners who travel to provide ploughing services to farmers in the district which is underprivileged in terms of tractor numbers, but has more farmlands and lower population density. There were no significant for Zaria in terms of cropland expansion during the survey period. With regard to time effect, cropland expansion was significantly higher in 2017 and 2018. Two interaction terms were introduced in the model to assess whether there are differential Effects of mechanization on cropland expansion across the three districts. The results show that the Effect of mechanization on farmland expansion is significantly higher among farmers in Igabi and significantly compared to Zaria. This result may be driven by differences in access to tractors in the districts with Igabi having the highest access, then followed by Zaria. 


\section{CONCLUSION}

Mechanization is need based process which provide sufficient time gap for self-adjustment of various inputs which ultimately gives positive effect on agricultural production. Average labour employment per cropped hectare were estimated at 53.36, 70.04-, 68.87-, 87.45and 147.9-mandays for TOF, THF, PTOF, PTHF and $\mathrm{BOF}$, respectively. It had been observed that human labour employment per cropped hectare in the study area was lower for mechanized farm than BOF. Labour displacement was highest for TOF where employment of labour was $36.08 \%$, followed by PTOF (46.57\%). Labour employment per cropped hectare showed a declining trend with increase in farm group size under different categories of mechanized and BOF.

Again, human labour employment was less in the case of mechanized farm than BOF such as ploughing, harvesting threshing and transportation. On the other hand, labour employment was found to be more in all mechanized farm than BOF for operation such as manuring, fertilization, intercultural operation and irrigation. Labour employment and farm size had inverse relationship within different categories of mechanized and BOF. Out of total labour employment, family labour employment was 3.70, 58.91, 20.30, 63.02 and $91.22 \%$ for TOF, THF, PTOF, PTHF and BOF, respectively.

The study also assessed the effects of tractor ploughing on cropland expansion and in northern Nigeria where farm mechanization is expected to produce the highest effect on agricultural production. Farm mechanization seems to have positively affected cropland expansion during the survey period. It is likely that mechanization. Higher maize yields were observed on the mostly silt-loam soils of Igabi $(1,031 \mathrm{~kg} / \mathrm{ha})$ compared to the predominantly sandy-loam soils of Zaria $(545 \mathrm{~kg} / \mathrm{ha})$. Mechanization has contributed to increased agricultural production in northern Nigeria. Ploughing with a tractor was essential for expanding croplands.

Today, there are still very few tractors in the country, and most farmers continue to till their fields manually. However, tractor use is growing quickly, and the effects that tractors have on Farm land expansion have given rise to fears between mechanization and land tenure.

\section{ACKNOWLEDGEMENTS}

My appreciation goes to Tractor Owners and Operators Association of Nigeria and the Faculty of Agricultural Sciences, National Open University of Nigeria, for the support given.

\section{REFERENCES}

Braimoh A.K. (2009). Agricultural land-use change during economic reforms in Nigeria. Land Use Policy, 26 (3), 763-771

Chamberlain G. (1984). Panel data. In: Grilliches Z. and Intriligator D.M. (eds.), Handbook of Econometrics, Vol. 2, Elsevier, Amsterdam.

Hazarika C. (2015). Labour scarcity in agriculture and farm mechanization. Nigerian Journal of Economics, 70 (1), 24-28

Manyong V.M., Ikpi A., Olayemi J.K., Yusuf S.A, Omonona R. and Idachaba F.S. (2003). Agriculture in Nigeria: Identifying Opportunities for Increased Commercialization and Investment. Main Report, International Institute of Tropical Agriculture (IITA), USAID/NIGERIA, \& Univ. of Ibadan

Mundlak Y. (1978). On the pooling of time series and cross section data. Econometrical, 46 (1), 69-85

Pingali P. (2007). Agricultural mechanization: Adoption patterns and economic effect. In Evenson R. and Pingali P. (eds.), Handbook of Agricultural Economics, Vol. 3. Elsevier, Amsterdam

Ramya P. and Muruganandham V. (2016). Effect of agricultural mechanization on production, productivity and employment of labour. Shanlax International Journal of Commerce, 4 (3), 54-60

Shani B.B. (2020). The upsurge of farm mechanization and its impact on land occupancy system in Nigeria. Journal of Engineering Research \& Reports, 18 (3), 36-45

Tersiguel P. (1995). Le Pari du Tracteur: La modernisation de l'Agriculture Cotonnière au Nigeria. Paris: Editions de l'Orstom

Van den Berg M.M., Hengsdijk H., Wolf J. et al. (2007). The impact of increasing farm size and mechanization on rural income and rice production in Zheijiang Province. Agricultural Systems, 94 (3), 841-850

Verma S.R. (2006). Effect of Agricultural Mechanization on Production, Productivity, Cropping Intensity Income Generation and Employment of Labour. Punjab Agric. Univ. Press, Status of Farm Mechanization in India, India

World Bank (2012). World Development Indicators 2012. Washington, DC. (C) World Bank. https://openknowledge. worldbank.org/handle/10986/6014 License: CC BY 3.0 IGO 